\title{
Invited review: Anti-adhesive properties of bovine oligosaccharides and bovine milk fat globule membrane-associated glycoconjugates against bacterial food enteropathogens
}

\author{
T. Douëllou, ${ }^{*} \dagger$ M. C. Montel, ${ }^{*}$ and D. Thevenot Sergentet $+\ddagger^{1}$ \\ *Institut National de Recherche Agronomique, UR 545 Unité de Recherches Fromagères, 15000 Aurillac, France \\ †Université de Lyon, Bacterial Opportunistic Pathogens and Environment Research Group, UMR5557 Ecologie Microbienne Lyon, \\ Université Lyon 1, CNRS (National Center of Scientific Research), VetAgro Sup, 69280 Marcy-l'Etoile, France \\ ‡Université de Lyon, VetAgro Sup-Campus Vétérinaire, Laboratoire d’Etudes des Microorganismes Alimentaires Pathogènes-French National \\ Reference Laboratory for Escherichia coli including Shiga toxin-producing E. coli (NRL-STEC), 69280, Marcy-l'Etoile, France
}

\begin{abstract}
The prevalence of the main raw milk and raw milkderived dairy product enteropathogens (Campylobacter, Shiga toxin-producing Escherichia coli, Listeria, and Salmonella) is higher than the number of epidemiological cases related to ingesting these foodstuffs. Bovine milk oligosaccharides and milk fat globule membrane (MFGM)-linked glycoconjugates interact with foodborne enteropathogens to inhibit their adhesion to intestinal cells and tissues. This review examines the main mechanisms and strategies used by enteropathogens to adhere to their target, details the anti-adhesive properties of MFGM against enteropathogens and enterotoxins, assesses the integrity of bacteria-MFGM complexes during dairy product manufacture and digestion, and discusses the potential for using these macromolecules and glycoconjugates in foods for public health.
\end{abstract}

Key words: bacterial enteropathogen, adhesion inhibition, milk fat globule, glycoconjugate, oligosaccharides

\section{INTRODUCTION}

The main gastrointestinal foodborne bacteria are a major public health concern worldwide due to the high incidence of cases in recent years, with numerous people developing infection and intoxication and eventually dying as a result of foodborne outbreaks. Foodborne disease outbreaks cause billions of dollars' worth of damage to public health, the food industry, medical expenses, hospitalization, and work stoppages, as well as food spoilage. Prevalences of Campylobacter,

Received June 14, 2016.

Accepted December 14, 2016.

${ }^{1}$ Corresponding author: delphine.sergentet@vetagro-sup.fr pathogenic Escherichia coli, Listeria, and Salmonella in raw milk and raw milk-derived dairy products range from 0 to $40 \%, 0$ to $33.5 \%$ ( $89.8 \%$ in France), 1 to $60 \%$ (45.3\% in Spain; Rodriguez et al., 1985), and 0 to $11.8 \%$, respectively, depending on the method of detection (Kai and Aotearoa, 2009; Lebrero et al., 2015). However, epidemiological studies show that this class of product is only a minor source of enteric human infections (EFSA, 2015). Only 27 outbreaks related to milk or dairy product consumption were reported in Europe between 2007 and 2012 (EFSA, 2015): 21 related to Campylobacter (236 cases between 2007 and 2012), 1 to Salmonella Typhimurium (3 cases in 2010), 2 to Shiga toxin-producing E. coli (31 cases in 2008 and 2012), and 3 to tick-borne encephalitis virus (34 cases in 2007 and 2010). Interestingly, prevalence data on these enteropathogens in dairy matrices and ingestion-related outbreaks do not fit overall foodborne-related outbreak figures (EFSA and ECDC, 2014; EFSA, 2015).

To effectively colonize a host and cause disease, many intestinal bacterial pathogens have evolved mechanisms and strategies for attaching or adhering to host cells and tissues (Ofek et al., 2003; Kaper et al., 2004). Adhesion is required so that the organisms are not swept away by the host's natural self-cleaning mechanisms. The most common means of adhesion, used by numerous bacteria, are surface fimbriae, curli, and lectins that interact with complementary carbohydrates and other components present on host cell surfaces (Rivero-Urgëll and Santamaria-Orleans, 2001; Boehm and Stahl, 2007; Tao et al., 2008). Different studies have focused on glycoconjugates (carbohydrates, called glycocalyx, covalently bound with macromolecules such as proteins or lipids; Figure 1) linked to the milk fat globule membrane (MFGM; Sprong et al., 2002; Quintero et al., 2011; Ghosh and Mehla, 2012; Quintero-Villegas et al., 2013) as suitable host epithelial cell mimetic receptors. These MFGM-linked glycoconjugates could therefore act as efficient decoys competing with the natural adhe- 


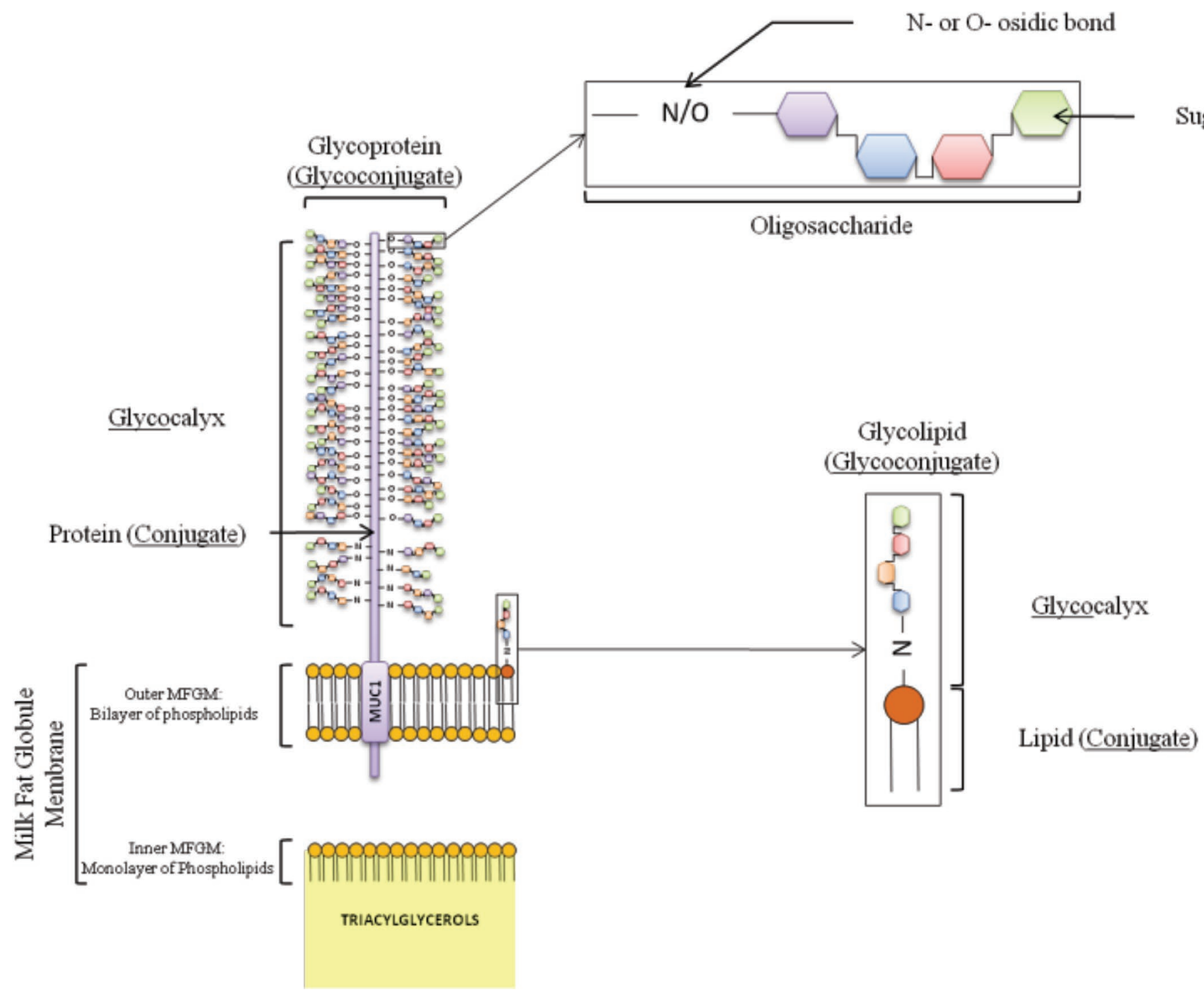

Figure 1. Schematic representation (not to scale) of milk fat globule membrane (MFGM)-associated glycoconjugates. MUC1 = Mucin 1. Color version available online.

sion targets of enteropathogens (Newburg et al., 2005; Bao et al., 2007).

Bovine milk fat is present as small droplets called milk fat globules (MFG) delimited by the MFGM. These MFG are coated with a complex mixture of glycoconjugates, such as glycoproteins and glycolipids, and enzymes (Figure 2; Keenan and Patton, 1995; Mather and Keenan, 1998; Gopal and Gill, 2000; Mather, 2000). In addition to the many beneficial effects of bovine raw milk, its glycoproteins, glycolipids, and milk carbohydrates have anti-adhesive properties against several intestinal pathogens (Dewettinck et al., 2008; Ebringer et al., 2008; Mills et al., 2011). Several interesting research studies have focused on the role of fucosylated oligosaccharides, mainly in human milk
(Barile and Rastall, 2013), and growth of bifidobacteria that are beneficial to human health (Barile and Rastall, 2013). Nonetheless, only $0.01 \%$ of bovine milk might be fucosylated, depending on the cow's stage of lactation (Tao et al., 2008, 2009; Simeoni et al., 2015). Thus, the Barile approach will not be developed in this review as overlooking other aspects of milk fat globules and antiadhesive properties of bovine milk oligosaccharides.

This review aims to explore the state of knowledge on the anti-adhesive properties of MFGM glycoconjugates and associated oligosaccharides that inhibit bacterial pathogen adhesion to the intestinal epithelial layer. Formation of the MFG and MFGM are presented in the first part. We then detail the anti-adhesive properties of MFGM against the main enteric bacterial pathogens 


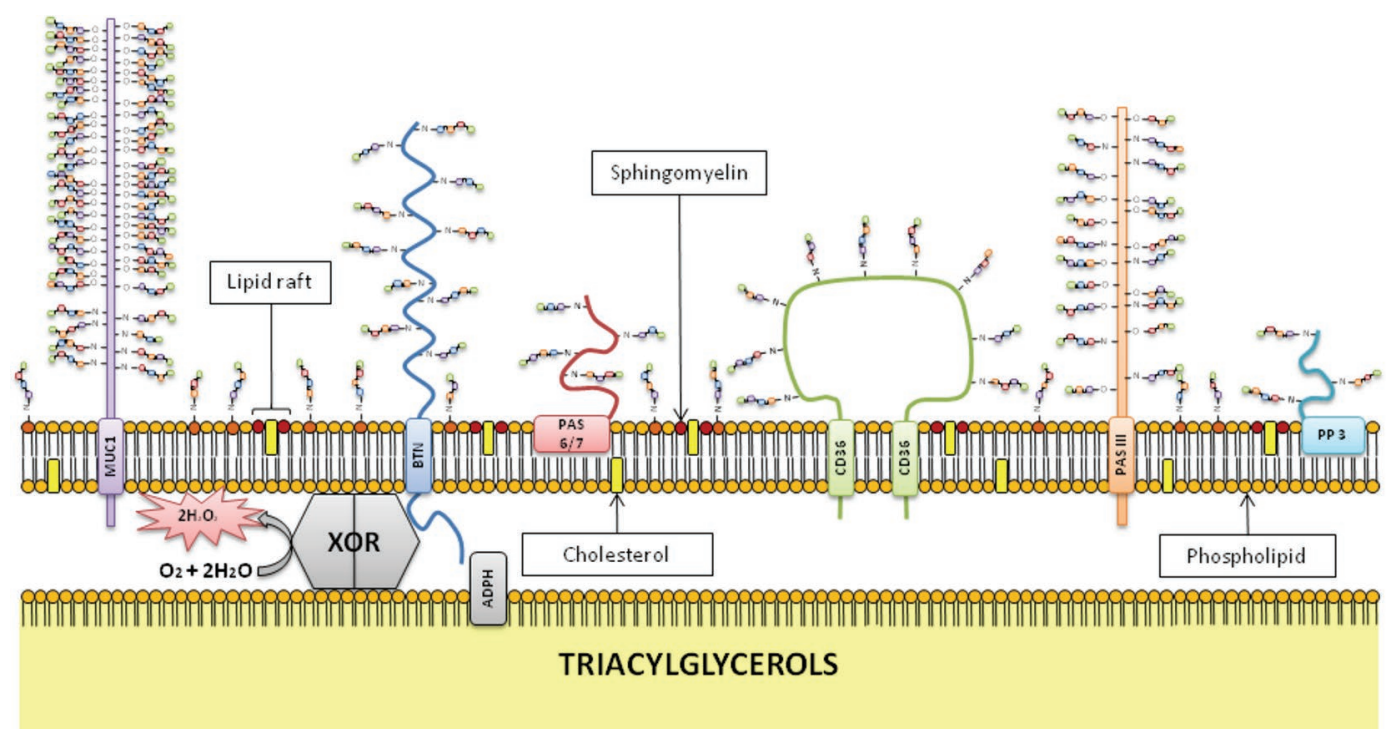

Figure 2. Organization of components (not to scale) in the milk fat globule membrane (MFGM) adapted from Dewettinck et al. (2008) and Lopez (2011): Milk fat globules are coated with proteins (glycoproteins and enzymes), lipids (phospholipids and cholesterol) and oligosaccharides (Gopal and Gill, 2000; Goudedranche et al., 2000; Michalski et al., 2003). Proteins and glycoproteins represent 25 to $70 \%$ of MFGM mass but account for only 1 to $2 \%$ of total milk protein. These membrane proteins are present in low proportions in the aqueous phase of milk (Deeth, 1997; Riccio, 2004; Walstra et al., 2005; Dewettinck et al., 2008). Seven to eight major proteins were identified and characterized by SDS-PAGE: mucin 1 (MUC1), xanthine dehydrogenase/oxidase (XDH/XO), CD36, PAS-6/7, adipophilin (ADPH), and butyrophilin (BTN). XOR: xanthine oxido-reductase; PAS III: periodic acid Schiff III; PAS 6/7: periodic acid Schiff 6/7; PP3: proteose peptone 3; CD36: cluster of differentiation 36. Many of these proteins present at the interface of the aqueous phase and the MFGM are heavily glycosylated (Mather, 2000; Dewettinck et al., 2008). Color version available online.

and assess the integrity of bacteria/MFGM association complexes during dairy product manufacture and digestion. We will conclude by discussing the potential for using these macromolecules and glycoconjugates in foods for public health.

\section{MILK FAT GLOBULES}

Bovine raw milk is a physiological liquid that provides several nutrients and bioactive elements; it contains approximately $5 \%$ lactose, $3.2 \%$ protein, $4 \%$ lipid, and $0.7 \%$ mineral salts (Séverin and Wenshui, 2005). The composition of milk varies greatly between species and individual breeds, and according to feeding, length of dry period, and time in lactation of the cows. It is also highly dependent on the methods of analysis used (Gopal and Gill, 2000). In addition, 95\% of milk fat is contained in MFG surrounded by a trilayer membrane of phospholipids - the MFGM. The majority of MFGM comprises specific membrane proteins, mainly glycoproteins (proteins with oligosaccharide chains; Figure 1), phospholipids, and sphingolipids (Keenan and Patton, 1995; Dewettinck et al., 2008). The membrane further comprises unique polar glycolipids and specific glycoproteins, including enzymes (Figure 2). Using specific fluorescent labeling, Lopez et al. (2010, 2011) demonstrated the organization of glycosylated molecules at the surface of bovine MFG. Confocal images showing glycosylate molecules around MFG in situ in milk are presented in Figure 3.
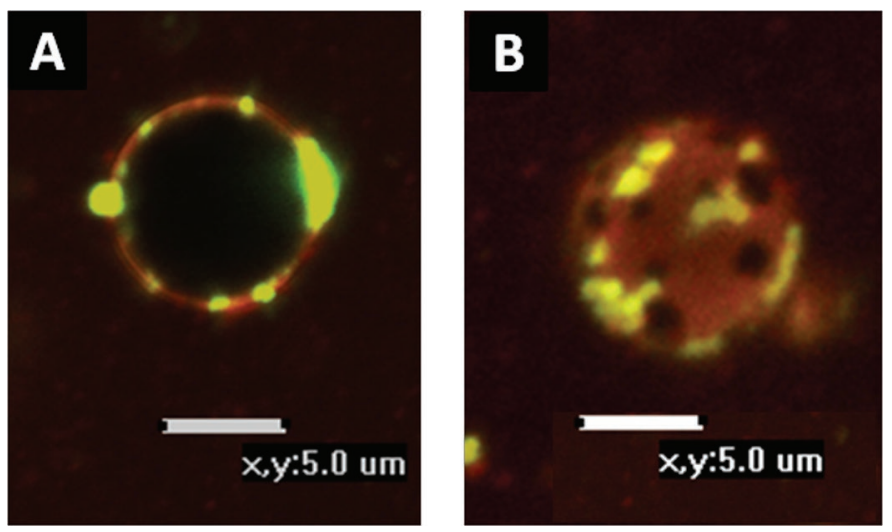

Figure 3. Confocal laser scanning micrographs corresponding to the emission fluorescence of the lectin wheat germ agglutinin used to localize the carbohydrate moieties in the milk fat globule membrane (bright/green) and the exogenous fluorescently labeled phospholipid $N$-(lissamine rhodamine B sulfonyl) di-oleoyl-phosphatidylethanolamine (dark/red). The images show the heterogeneous distribution of glycoproteins and glycolipids (bright/green) in the milk fat globule membrane. (A) Transversal view of milk fat globule (MFG); and (B) MFG surface. Scale bars $=5 \mu \mathrm{m}$. Adapted from Lopez et al. (2010). Color version available online. 


\section{Formation of MFG}

Milk fat is dispersed in the form of milk fat globules, and $95 \%$ of triglycerides in milk are located in the core of MFG (Keenan and Patton, 1995; Mather and Keenan, 1998; Collins et al., 2003; Heid and Keenan, 2005; Lopez, 2011). The MFG are initially formed in the endoplasmic reticulum of mammary gland cells and are released into the cytosol as droplets. They are delimited by a monolayer membrane originating from the cytoplasmic leaflet of the endoplasmic reticulum membrane (Heid and Keenan, 2005; Truong et al., 2016). Their mean diameter varies between 0.1 and 20 $\mu \mathrm{m}$, with an average of approximately $4 \mu \mathrm{m}$ depending on cow breed and season (Keenan et al., 1983; Lopez et al., 2006, 2010; Ménard et al., 2010; Lopez, 2011; Mesilati-Stahy et al., 2015). In addition, the size of MFG seems to be regulated by lactating stage and free fatty acids content of MFG (Mesilati-Stahy et al., 2015). The size of MFG and parameters affecting size were reviewed in Lopez (2011). Mechanisms underlying the intracytosolic fusion and secretion of MFG appear to be highly regulated (Couvreur et al., 2007; Lopez, 2011; Altenhofer et al., 2015). Nevertheless, this mechanism of secretion by mammary cells is still controversial and not well understood (Wooding and Sargeant, 2015). After their migration through the cytosol, MFG are exocytosed by mammary epithelial cells during the lactating process and are surrounded by a new layer of plasma membrane. The excreted MFG is delimited by a trilayer of phospholipids, a monolayer and a bilayer originating from differentiated regions of apical plasma membrane, that are abstracted as the MFGM.

\section{Composition of MFGM}

The MFG are coated with a complex mixture of proteins, including glycoproteins and enzymes, lipids such as phospholipids and cholesterol, and other minor components such as vitamins, oligosaccharides, and ions (Keenan and Patton, 1995; Dewettinck et al., 2008). The surface area of the MFGM depends on the MFG size and ranges between 5 and $11 \mathrm{~m}^{2}$ per $100 \mathrm{~g}$ of milk (Walstra, 1995; Michalski et al., 2003). For a given MFG concentration, this surface area is greater for small MFG than for larger MFG (Michalski et al., 2003).

Lipids. Bovine milk fat has been analyzed using chromatographic and spectrometric methods to identify nearly 400 fatty acids. Most of these 400 fatty acids are present in small amounts $(<0.01 \%)$, but 15 fatty acids are present at $\geq 1 \%$. Because of the high variability of fatty acid composition in milk, typical values are measured for cows in mid-lactation and grazing mature pasture (MacGibbon and Taylor, 2006). Almost $60 \%$ of all phospholipids are associated with the MFGM and they represent approximately $1 \%$ of the total milk lipids. The main phospholipids are phosphatidylcholine, phosphatidylethanolamine, and sphingomyelin (Banks, 1991; Rombaut and Dewettinck, 2007; Dewettinck et al., 2008; Lopez, 2011).

Proteins and Glycoproteins. Protein represents 25 to $70 \%$ of MFGM mass but only 1 to $2 \%$ of total milk protein. These membrane proteins are present in low proportions in the aqueous phase of milk (Deeth, 1997; Riccio, 2004; Walstra et al., 2005; Dewettinck et al., 2008). Nevertheless, based on the size of MFG, the exchange surface of MFGM glycoproteins and the aqueous phase may be important (Michalski et al., 2003). Several works, reviewed by Mather (2000) and Dewettinck et al. (2008), aimed to characterize these proteins identified 7 or 8 major proteins by SDS-PAGE. Among them, mucin 1 (MUC1), xanthine dehydrogenase/ oxidase (XDH/XO), CD36, PAS-6 and PAS-7, adipophilin (ADPH), and butyrophilin (BTN) have been characterized. Many of these proteins present at the interface of MFGM and the aqueous phase are heavily glycosylated (Mather, 2000; Dewettinck et al., 2008).

Milk Oligosaccharides. Oligosaccharides are defined as carbohydrates with 3 to 10 monosaccharides covalently linked by glycosidic bonds. Tao et al. (2008) demonstrated that almost 40 bovine oligosaccharides are present in milk. The monomers of milk oligosaccharides are D-glucose (Glc), D-galactose (Gal), Nacetylglucosamine (GlcNAc), L-fucose (Fuc), $N$-acetylneuraminic acid (NeuAc), and $N$-glycolylneuraminic acid (NeuGc) (Rivero-Urgëll and Santamaria-Orleans, 2001; Boehm and Stahl, 2007; Tao et al., 2008, 2009; Aldredge et al., 2013).

\section{MECHANISMS AND STRATEGIES OF ADHESION}

Adhesion is critical to the survival of pathogenic enteric bacteria. It enables targeting to a specific surface and, in flow environments, enables bacteria to resist physical detachment by hydrodynamic shear forces (Figure 4; Klemm and Schembri, 2000; Pizarro-Cerdá and Cossart, 2006). Attachment of pathogenic bacteria to host surfaces is a critical step in the pathogenesis of several gastrointestinal tract infections. It also gives the pathogens better access to sources of nutrition, facilitates the delivery of toxic agents into host issues, and, ultimately, enables the bacteria to penetrate into tissues (Sharon, 2006).

Bacterial attachment may involve specific interactions between specialized proteins and receptors present at the host cell surface (Lis and Sharon, 1998). Enteric pathogenic bacteria use different strategies to bind tar- 
get host cells or tissues and several means of adhesion, such as capsule, fimbriae, pili, and other glycan-binding surface proteins (lectins; Esko and Sharon, 2009; Haiko and Westerlund-Wikström, 2013). As a rule, bacterial adhesins typically target sugar moieties of glycoproteins or glycolipids by a carbohydrate-recognition domain located at the terminal end of the adhesin tip (Esko and Sharon, 2009; Jaglic et al., 2014). In several cases, the receptor target of bacterial adhesins has a known molecular structure (Klemm and Schembri, 2000; Klemm et al., 2010).

Adhesins are a group of proteins in enterohemorrhagic Escherichia coli (EHEC) that enable pathogen-to-host attachment or colonization. More precisely, intimin and Tir are involved in the development of attaching and effacing lesion (McWilliams and Torres, 2014). A suite of fimbrial proteins [long polar fimbriae $(\mathbf{L p f})$ 1, Lpf2, curli, E. coli common pilus (ECP), F9, E. coli laminin-binding fimbriae (ELF), hemorrhagic coli pilus (HCP), and type-1 fimbria] play a role in EHEC adhesion to abiotic and biological surfaces (Croxen and Finlay, 2010). The capacity of Listeria monocytogenes to cause disease is reliant on its ability to survive in the macrophage, invade, and replicate in nonphagocytic cells and cross the intestinal barrier. Internalin (InlA or InlB) proteins play a role in this invasiveness (PizarroCerdá et al., 2012). Finally, unlike E. coli or Salmonella, adhesion of Campylobacter is not mediated by fimbria or pili. Rather, Campylobacter interact with host cells in a complicated process involving a plethora of bacterial cell surface structures interacting with particular cell receptors. Attachment of Campylobacter may involve glycan-lectin interaction (Rubinchik et al., 2012).

\section{Inhibition of Adhesion by Pathogenic Bacteria}

Several natural food components have been shown to act as efficient inhibitors of pathogen adherence (Virkola et al., 1993; Quintero et al., 2011; QuinteroVillegas et al., 2013). It was shown that the fimbrial end tip protein and the sugar moieties found at host cell surfaces generally have low affinity (Esko and Sharon, 2009). This suggests that oligosaccharide decoys might compete with natural targets of enteropathogens.

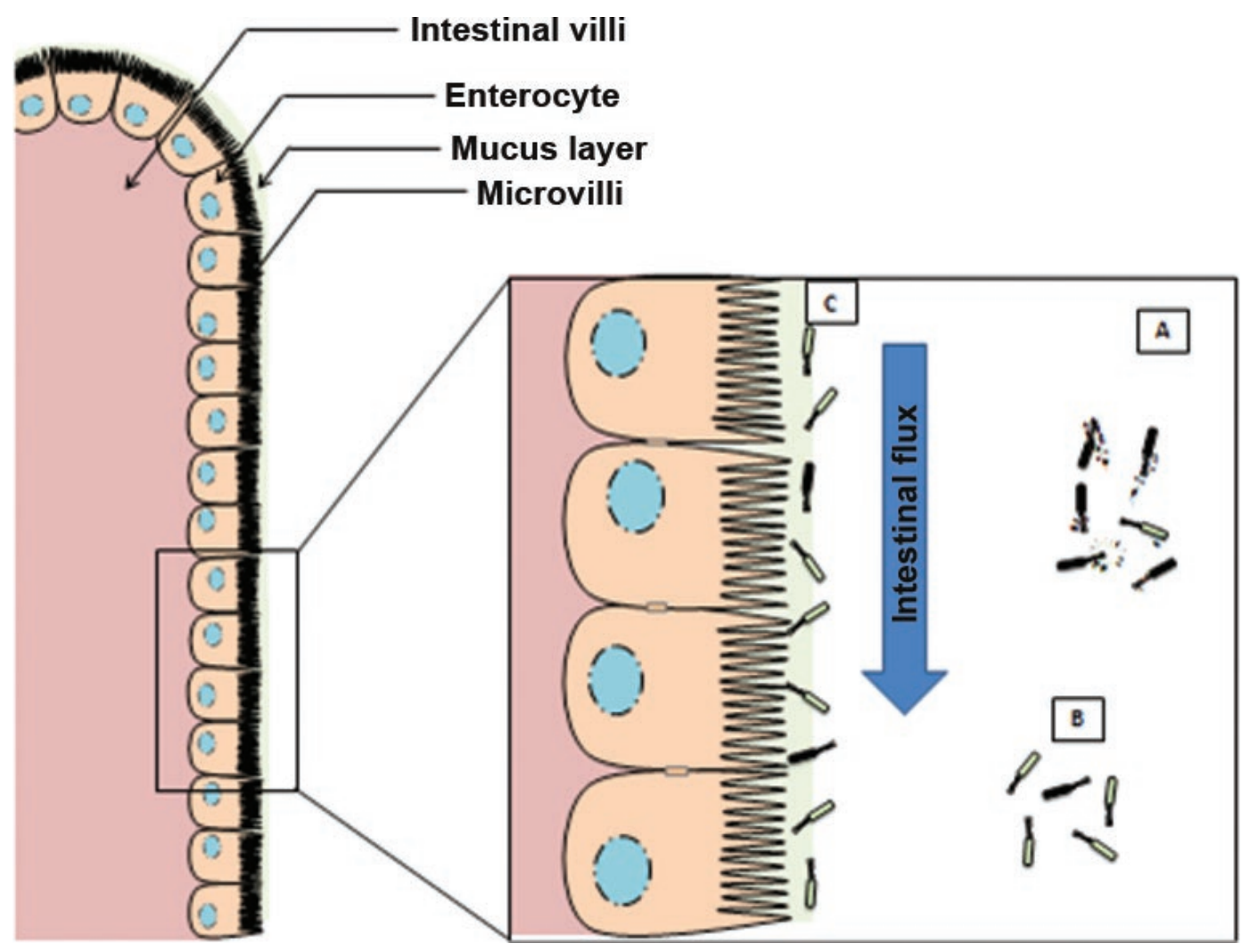

Figure 4. Schematic representation (not to scale) of the effect of milk fat globule/milk fat globule membrane (MFGM) on bacterial adhesion to intestinal tissues. (A) Partially disrupted MFGM leading to dissemination of glycoproteins in the luminal part of the intestine. Bacteria use glycoproteins as receptor-like molecules competing with natural receptors. (B) Few bacteria remain free of glycoconjugates and therefore are swept away from the gastrointestinal tract. (C) Bacteria adhered to intestinal tissues, leading them to disseminate and establish effective niches. Black $=$ representation of pathogenic bacteria; white $=$ representation of natural microbiota. Color version available online. 
Competition for natural binding sites of pathogenic bacteria with mimetic receptors may inhibit pathogen anchoring. Because colonization by pathogens is one of the first steps of host infectivity, milk components may act as protective agents. The large availability of MFGM-linked glycoconjugates for enteropathogen bacteria is due to the large exchange surface of MFG with the aqueous phase (Walstra, 1995; Michalski et al., 2003). As an example, Guri et al. (2012) showed a strong inhibitory effect of bovine and goat MFG on Salmonella Enteritidis adhesion to HT-29 human adenocarcinoma cells. Interestingly, defatted MFGM appears to modulate virulence gene expression of $E$. coli O157:H7 (Tellez et al., 2012). Nonetheless, the effect of defatted MFGM on E. coli gene expression will not be detailed here.

\section{Milk Oligosaccharides and Glycocalyx}

There is growing evidence that bovine oligosaccharides and MFGM-associated glycoconjugates are used not only as an energy source for microbiota but are also soluble receptors that mimic epithelial cell surface carbohydrates. These glycoconjugates, associated glycocalyxes, and several milk oligosaccharides act as competitors or interact with natural receptors of these pathogens target cells (Gopal and Gill, 2000). The anti-adhesive properties of MFGM glycoconjugates are essentially dependent on glycocalyx composition and structure.

Most bovine milk oligosaccharides are tri- and tetrasaccharides, which are highly polarized; nearly $70 \%$ of these carbohydrates contain sialic acid residues in the form of $\mathrm{N}$-acetylneuraminic acid and $\mathrm{N}$-glycolylneuraminic acid (Tao et al., 2008). The fact that sialylated oligosaccharides in bovine milk can inhibit bacterial adherence was first established by Virkola et al. (1993), who showed that sialylated lactose strongly bound $E$. coli S-fimbria. Evidence also suggests that sialic acid modulates expression of the fim operon, which is implicated in the synthesis of type- 1 fimbria in several potential pathogens, including E. coli (Sohanpal et al., 2004). This operon is also present in pathogenic strains of Salmonella and Klebsiella but it has not yet been determined whether sialic acid is implicated in its regulation in those species (Klemm and Schembri, 2000; Stahlhut et al., 2009; Blomfield, 2015).

Another study showed that sialylated oligosaccharides inhibit adhesion of Helicobacter pylori to monolayer duodenum-derived cell line HuTu-80 cultures (Simon et al., 1997). Similarly, bovine sialylated oligosaccharides were shown to be effective hemagglutination inhibitors in uropathogenic E. coli (UPEC) and enterotoxigenic $E$. coli (ETEC) strains (Martin-Sosa et al., 2002). Parker et al. (2010) showed that the inhibition of adhesion of E. coli and Salmonella serovar Typhimurium to Caco-2 cells seems to be structure-dependent with sialic acid, L-fucose, and D-mannose monosaccharides. Another study demonstrated the effect of bovine colostrum oligosaccharides on the adhesion of enteropathogenic Escherichia coli, Cronobacter sakazakii, and Salmonella enterica serovar Typhimurium to HEp-2 cell monolayers cultured in vitro (Maldonado-Gomez et al., 2015).

\section{Association of MFGM and Bacteria}

Evidence of bacterial association with the MFG phase has been known for decades. Dean et al. (1959) reported that bacteria have a tendency to aggregate at the MFG surface. Laloy et al. (1996) showed that lactic acid bacteria are strongly associated with MFG residues in cheese matrices and mainly present in the MFGM, principally as ghost cells. Lopez et al. (2006) observed in Emmental cheese that bacteria were preferentially localized at the fat-protein interface. An electron microscopy study of pasta filata mozzarella observed aggregations of chains and rods of bacteria in sites originally occupied by MFG and MFGM residues (Kuo and Gunasekaran, 2009). Those authors confirmed that most bacteria in this cheese were located at the fat-protein interface. Using confocal laser scanning microscopy, Brisson et al. (2010) observed interactions between bacteria and MFGM. Finally, electron micrographs by Martinovic et al. (2013) showed that lactococci used as starter culture in cheese seemed to be associated with fat globules. Hickey et al. (2015) recently reviewed bacterial localization in dairy food matrices.

\section{Lipids and Glycolipids}

Because many bacteria and toxins use glycosphingolipids as binding sites to host cells, exogenous milk sphingolipids could have a protective effect against pathogens by competing for or acting as cellular-like pathogen binding sites (Fantini et al., 1997).

The distribution of polar lipids in the MFGM appears to be heterogeneous (Evers et al., 2008; Lopez et al., 2010). Milk fat globule membrane micro-domain "lipid rafts" are mainly composed of sphingomyelin (Lopez et al., 2010). These lipid rafts originate directly from the apical mammary epithelial cells (Lopez et al., 2010) and may feature cholesterol entrenchment. Sprong et al. $(2001,2002)$ reported the bactericidal effect of sphingolipids against Campylobacter jejuni, Listeria monocytogenes, and Clostridium perfringens. They also demonstrated a decrease in viable $E$. coli and Salmonella enteritidis after in vitro treatment with 
sphingolipid macromolecules. Sánchez-Juanes et al. (2009) demonstrated an in vivo effect of glycosphingolipids on the intestinal colonizability of ETEC strains by binding the pathogens.

The MFGM can contain other minor lipids including ceramides, cerebrosides, gangliosides, and cholesterol, which is the major sterol in milk (cholesterol accounts for $\sim 95 \%$ of total sterols in milk). The major gangliosides in bovine milk are GD3 and GM3. Gangliosidesupplemented formula appeared to diminish E. coli rate of infection in preterm infants (Rueda et al., 1998) and inhibit the intestinal inflammatory response due to $E$. coli lipopolysaccharides (Park et al., 2007).

Although the structure-function relationship of lipids in milk is not yet understood, the lipid fraction of the MFGM appears to play a less important role than the glycoconjugate fraction in anti-adhesive activity against H. pylori (Wang et al., 2001).

\section{Proteins and Glycoproteins}

The ability of bovine MFGM-bound glycoproteins to inhibit pathogen adhesion was only recently confirmed (Wang et al., 2001; Parker et al., 2010; Ross et al., 2016). Bacterial lectin, a bacterial-like fimbria-associated protein, selectively binds to butyrophilin, CD36, MUC1, MUC15, and PAS-6/7 (Shahriar et al., 2006; Parker et al., 2010; Struijs et al., 2013). Mucins are widely shown to demonstrate anti-adhesion activity, and they belong a heavily glycosylated family of glycoproteins (Schroten et al., 1992; Kvistgaard et al., 2004).

Bovine MFGM and defatted MFGM fractions both inhibited hemagglutination of $H$. pylori at similar concentrations and reduced $H$. pylori binding to HeLa S3 cell monolayers (Wang et al., 2001). Sando et al. (2009) showed that purified bovine MUC1 directly bound fluorescently labeled Escherichia coli bioparticles and inhibited their binding to bovine mammary epithelial cells grown in vitro. $N$-Acetylglucosamine and $N$-acetylgalactosamine (GalNAc) also significantly inhibited E. coli adhesion, whereas galactose, one of the most abundant MUC1 monosaccharides, showed the strongest inhibition against Salmonella Typhimurium (Parker et al., 2010). A study on human milk reported that the mucin fraction of MFGM inhibited adhesion of S-fimbriated Escherichia coli to buccal epithelial cells (Schroten et al., 1992).

Studies on other components (Struijs et al., 2013) have demonstrated that the MUC1 fraction of MFGM glycoproteins has a strong inhibitory effect against microbiota adhesion to a mucus-enriched agar, whereas the PAS-6/7 fraction had a neutral effect. However, the total MFGM glycoprotein fraction showed a greater anti-adhesion effect than the MUC1 and MUC1/PAS-
6/7 fractions. These data suggest that other MFGMassociated components are implicated in the inhibition of bacterial adhesion, and that these milk components could have a synergistic effect against microbial adhesion (Struijs et al., 2013).

Wang et al. (2001) showed that milk components such as glycomacropeptide and sialyllactose presented inhibitory properties against $H$. pylori adhesion to model cell monolayers, even if these components appeared to have a weaker effect than MUC1.

Milk fat globules also inhibited the ability of Listeria monocytogenes to adhere to the intestinal layer in rats fed milks containing different MFG concentrations (Sprong et al., 2001, 2002). However, Brisson et al. (2010) showed that cell surface characteristics of Lactobacillus reuteri influence the binding properties of the strains. The more hydrophobic strains are more able to adhere to MFGM. A strong association was found between strain hydrophobicity and presence of extractable cell surface proteins, suggesting that they might play a key role in the binding of these bacteria.

Peterson et al. (1998) suggested that lactalbumin and $\kappa$-casein-derived glycomacropeptide may inhibit bacterial adhesion to the gastric mucosa. Brück et al. (2006) demonstrated that milk glycomacropeptide and $\alpha$-lactalbumin effectively inhibited adhesion of enteropathogenic Escherichia coli (EPEC), Salmonella Typhimurium, and Shigella flexneri to CaCo-2 cultures.

The role of xanthine oxidoreductase (XOR) as an antimicrobial agent in the gastrointestinal tract is now well described in the literature. Located at the inter-space between the inner monolayer and the outer bilayer of the MFGM, this enzyme acts by producing reactive oxygen species, superoxide, and hydrogen peroxide in the gastrointestinal tract. It can also reduce nitrite to nitric oxide and peroxynitrite, which have strong antimicrobial properties (Martin et al., 2004; Harrison, 2006).

\section{Association of MFGM and Toxins}

Milk contains numerous mimetic receptors that help recognize bacterial toxins such as EHEC Shiga toxins, thermolabile and thermoresistant Salmonella toxins, or Vibrio cholerae enterotoxins (Minke et al., 1999). These receptor-likes compete for natural site of host cell action and help protect the organism. The Vibrio cholerae enterotoxin is an AB5 toxin that binds specifically to the Galß1-3GalNAc moiety of GM1 ganglioside (Minke et al., 1999). Similarly, Shiga toxin synthesized by Shiga toxin-producing E. coli binds to the Gal $\alpha 1-4$ Gal moiety on both glycolipids and glycoproteins (Esko and Sharon, 2009). Steil et al. (2015) led a deep structural analysis of the Stx receptor and identified globotriaosylceramide 
(Gb3Cer) and globotetraosylceramide (Gb4Cer) as the glycosphingolipid receptors for Shiga toxin variants Stx1a, Stx2a, and Stx2e, which are strongly associated with hemolytic uremic syndrome (HUS). Those authors also characterized globopentaosylceramide (Gb5Cer) as a receptor for Stx2e. Both Gb3Cer and Gb4Cer are well represented in MFG. These lipid rafts may play an antagonist role against Shiga toxin receptor recognition.

\section{MFGM STRUCTURE MODIFICATION}

\section{Dairy Products Manufacturing}

Bovine milk is mainly transformed into dairy products such as cheese, cream, yogurt, and ice cream. These various manufacturing processes can modify the molecules involved in the MFGM-bacteria association. Specifically, milk treatments for processing affect MFG and MFGM integrity in terms of glycoconjugates and associated oligosaccharides. These treatments include high-temperature treatment (Sharma and Dalgleish, 1993; Kim and Jimenez-Flores, 1995) that kills or limits the growth of bacteria present in raw milk; homogenization, which allows fat dispersion into drinking milk; and enzymatic reactions led by pressure and lactic acid bacteria for cheese making (Lopez et al., 2015).

Heat treatment (typically pasteurization) of milk is an effective process for inactivating pathogens. The MFGM-associated glycoproteins and glycolipids form a lace-like network of glycoconjugate filaments at the MFG oil-water interface, and these filaments are lost when milk is heated (Jensen et al., 1992). Thermal treatments of milk thus destroy the carbohydrates located at the MFGM surface, which means fewer carbohydrate-like receptors are available for bacteria, thereby inhibiting anti-adhesive properties of MFGM.

Industrial drinking milks are homogenized to maintain the dispersion of fat in the aqueous phase of milk (Lopez et al., 2015). Homogenization partially disrupts the MFGM and leads to the adsorption of milk casein. Moreover, homogenization induces a decrease in MFG diameter (ranging from 0.1 to $0.5 \mu \mathrm{m}$; Lopez, 2005). It also alters MFGM structure and modifies MFGM composition (Keenan et al., 1983; Sharma and Dalgleish, 1993), with the result that coated carbohydrates are less available at the aqueous-fat interface for enteropathogens.

The many varieties of cheeses produced can be broadly divided into 4 categories: soft, semi-soft, semihard, and hard. The different processing technologies used in various cheese types affect the fat structure. Cheese fat can be found as native MFG surrounded by MFGM, an aggregate of MFG, free fat, or fat associated with whey proteins. Interactions between MFG surface and protein matrix affect the structure and texture of dairy products. Interestingly, MFG do not interact with protein but act mainly as fillers (Michalski et al., 2003; Lopez et al., 2015) that partially destroy the MFGM and thus leave enteric pathogens fewer carbohydrate decoys to target. Two mechanisms are possible: (1) the MFGM does not surround MFG but remains in the dairy product, in which case, the carbohydrates are available for enteric pathogens; or (2) all components of the MFGM are lost in the whey and are not present in the dairy product.

Heat treatments and high mechanical treatments such as homogenization destabilize the structure of the MFGM during milk processing. Nonetheless, with the exception of pasteurization, glycoconjugates may remain intact through consumption of the dairy products. Glycoconjugates are the main set of macromolecules involved in the anti-adhesive properties of milk against enteropathogens.

\section{Digestion of MFGM}

Digestion takes place in the stomach, 3 segments of the human small intestine (i.e., duodenum, jejunum, and ileum), and the colon. During digestion, gastric $\mathrm{pH}$, gastrointestinal secretions, and peristalsis are key factors controlling the outcome of foodborne pathogens. Moreover, physico-chemical conditions and microbial content of the gastrointestinal tract alter the structure of the MFGM, leading to a release of MFGM glycoconjugates and digestion of the fat, proteins, and sugars. Here, we explore whether MFGM retains effective antiadhesive properties after passage through the human gastrointestinal tract.

The diversity and complexity of saccharidic monomers arrangements composing milk oligosaccharide glycoconjugates act as a layer of protection against digestive enzymes and hydrolysis by pepsin (Gallier et al., 2012; Le et al., 2012). Nevertheless, the hydrolase resistance of milk oligosaccharides appears to depend on the degree of glycosylation. Experiments by Kobylka and Carraway (1972) and Shimizu et al. (1979) demonstrated that MUC1 (heavily glycosylated) was highly resistant to the action of pepsin, whereas CD36 and PAS-6/7 (less glycosylated) were less resistant. Brück et al. (2006) showed that digestion of milk $\alpha$-lactalbumin and glycomacropeptide by pepsin or pancreatin did not affect their anti-adhesion properties against EPEC, Salmonella Typhimurium, and Shigella flexneri strains. Le et al. (2012) showed that integrity of Muc1, as well as a minor share of PAS III and a major share of CD36, were maintained after treatment with pepsin and a combination of trypsin and $\alpha$-chymotrypsin. The integrity of these glycoproteins was maintained 
based on their degree of glycosylation. Milk oligosaccharides are thus neither digested nor absorbed in the human upper intestinal tract but remain structurally and functionally intact during digestion (Gallier et al., 2012) and can be broken down in the colon, where they serve as nutrients for colonic microflora (Sabharwal et al., 1991; Chaturvedi et al., 2001; Coppa et al., 2001; Albrecht et al., 2011). To our knowledge, no study has yet determined the digestibility of lectin-associated oligosaccharides.

Although the digestion of MFG and MFGM affects their structural integrity, glycoconjugates appears to be intact in the colon. Nevertheless, the anti-adhesive properties of these molecules against enteropathogens have yet to be established in vivo.

\section{CONCLUSIONS AND PERSPECTIVES}

The enteropathogen prevalence-human cases paradox can be explained by interactions between the main mechanisms of bacterial adhesion and free or conjugated carbohydrates. Infections rely on bacterial attachment to intestinal epithelial cells. This review shows that raw milk-derived carbohydrates and glycoconjugates could be considered as diet components that limit the adhesion of enteric pathogenic bacteria to the human gut. More generally, prevention of bacterial adhesion is now regarded as a promising strategy for reducing infectious disease without the need for antibiotics. Several specific approaches have been investigated, including adhesion inhibition with receptor analogs or stoichiometric obstruction (Bouckaert et al., 2005). Natural receptor analogs able to inhibit pathogen adhesion to enterocytes in human gastrointestinal gut (by receptor analog or stoichiometric obstruction) are essential for human health. Blocking or inhibiting pathogen-host cell interactions by suitable carbohydrates or their analogs (synthetic glycoclusters) for the prevention and treatment of microbial diseases is the premise behind engineered "anti-adhesion therapies" for some of these pathogens (Simon et al., 1997; Kelly and Younson, 2000; Ofek et al., 2003). The use of MFGM glycosylated molecules (i.e., glycoproteins and glycolipids) could serve as a way to investigate diet-mediated prophylaxis against gastrointestinal tract pathogens. Development of a safe drug against enteric bacterial infection is therefore urgently required for public health and societal welfare. Components of the MFGM are ideal candidates for anti-adhesion therapy because they are unlikely to be toxic or immunogenic. Moreover, as anti-adhesive agents do not act by killing or arresting the growth of the pathogens, it is very likely that strains resistant to anti-adhesive agents would emerge at a far slower rate than antibiotic-resistant strains.

\section{ACKNOWLEDGMENTS}

The authors thank the Auvergne Regional Council, DRAAF Auvergne (Clermont-Ferrand, France), and French Ministry for Agriculture Directorate for Food Safety (DGAL; Paris, France) for funding this research.

\section{REFERENCES}

Albrecht, S., H. A. Schols, E. G. H. M. van den Heuvel, A. G. J. Voragen, and H. Gruppen. 2011. Occurrence of oligosaccharides in feces of breast-fed babies in their first six months of life and the corresponding breast milk. Carbohydr. Res. 346:2540-2550. https:// doi.org/10.1016/j.carres.2011.08.009.

Aldredge, D. L., M. R. Geronimo, S. Hua, C. C. Nwosu, C. B. Lebrilla, and D. Barile. 2013. Annotation and structural elucidation of bovine milk oligosaccharides and determination of novel fucosylated structures. Glycobiology 23:664-676. https://doi. org/10.1093/glycob/cwt007.

Altenhofer, C., W. Holzmüller, F. Wolfertstetter, D. Wolfschoon Ribeiro, U. Kulozik, M. W. Pfaffl, and E. Viturro. 2015. Temporal variation of milk fat globule diameter, fat and cholesterol content and milk epithelial cell gene expression in dairy cows. Int. J. Dairy Technol. 68:519-526. https://doi.org/10.1111/1471-0307.12220.

Banks, W. 1991. Milk fat. Int. J. Dairy Technol. 44:31-32. https://doi. org/10.1111/j.1471-0307.1991.tb00628.x.

Bao, Y., L. Zhu, and D. Newburg. 2007. Simultaneous quantification of sialyloligosaccharides from human milk by capillary electrophoresis. Anal. Biochem. 370:206-214. https://doi.org/10.1016/j. ab.2007.07.004.

Barile, D., and R. A. Rastall. 2013. Human milk and related oligosaccharides as prebiotics. Curr. Opin. Biotechnol. 24:214-219. https://doi.org/10.1016/j.copbio.2013.01.008.

Blomfield, I. C. 2015. Sialic acid and N-acetylglucosamine regulate type 1 fimbriae synthesis. Microbiol. Spectr. 3:95-103. https://doi. org/10.1128/microbiolspec.MBP-0015-2014.

Boehm, G., and B. Stahl. 2007. Oligosaccharides from milk. J. Nutr. $137: 847 \mathrm{~S}-849 \mathrm{~S}$.

Bouckaert, J., J. Berglund, M. Schembri, E. De Genst, L. Cools, M. Wuhrer, C. S. Hung, J. Pinkner, R. Slättegård, A. Zavialov, D. Choudhury, S. Langermann, S. J. Hultgren, L. Wyns, P. Klemm, S. Oscarson, S. D. Knight, and H. De Greve. 2005. Receptor binding studies disclose a novel class of high-affinity inhibitors of the Escherichia coli FimH adhesin. Mol. Microbiol. 55:441-455. https://doi.org/10.1111/j.1365-2958.2004.04415.x.

Brisson, G., H. F. Payken, J. P. Sharpe, and R. Jiménez-Flores. 2010. Characterization of Lactobacillus reuteri interaction with milk fat globule membrane components in dairy products. J. Agric. Food Chem. 58:5612-5619. https://doi.org/10.1021/jf904381s.

Brück, W. M., S. L. Kelleher, G. R. Gibson, G. Graverholt, and B. L. Lönnerdal. 2006. The effects of alpha-lactalbumin and glycomacropeptide on the association of Caco- 2 cells by enteropathogenic Escherichia coli, Salmonella Typhimurium and Shigella flexneri. FEMS Microbiol. Lett. 259:158-162. https://doi.org/10.1111/ j.1574-6968.2006.00268.x.

Chaturvedi, P., C. D. Warren, C. R. Buescher, L. K. Pickering, and D. S. Newburg. 2001. Survival of human milk oligosaccharides in the intestine of infants. Adv. Exp. Med. Biol. 501:315-323.

Collins, Y. F., P. L. H. McSweeney, and M. G. Wilkinson. 2003. Lipolysis and free fatty acid catabolism in cheese: A review of current knowledge. Int. Dairy J. 13:841-866. https://doi.org/10.1016/ S0958-6946(03)00109-2.

Coppa, G. V., P. Pierani, L. Zampini, S. Bruni, I. Carloni, and O. Gabrielli. 2001. Characterization of oligosaccharides in milk and feces of breast-fed infants by high-performance anion-exchange chromatography. Adv. Exp. Med. Biol. 501:307-314.

Couvreur, S., C. Hurtaud, P. G. Marnet, P. Faverdin, and J. L. Peyraud. 2007. Composition of milk fat from cows selected for milk fat globule size and offered either fresh pasture or a corn silage-based 
diet. J. Dairy Sci. 90:392-403. https://doi.org/10.3168/jds.S00220302(07)72640-1.

Croxen, M. A., and B. B. Finlay. 2010. Molecular mechanisms of Escherichia coli pathogenicity. Nat. Rev. Microbiol. 8:26-38. https:// doi.org/10.1038/nrmicro2265.

Dean, M. R., N. J. Berridge, and L. A. Mabbitt. 1959. Microscopical observations on cheddar cheese and curd. J. Dairy Res. 26:77-82. https://doi.org/10.1017/S0022029900009705.

Deeth, H. C. 1997. The role of phospholipids in the stability of milk fat globules. Aust. J. Dairy Technol. 52:44-46.

Dewettinck, K., R. Rombaut, N. Thienpont, T. T. Le, K. Messens, and J. Van Camp. 2008. Nutritional and technological aspects of milk fat globule membrane material. Int. Dairy J. 18:436-457. https:// doi.org/10.1016/j.idairyj.2007.10.014.

Ebringer, L., M. Ferencík, and J. Krajcovic. 2008. Beneficial health effects of milk and fermented dairy products-Review. Folia Microbiol. (Praha) 53:378-394. https://doi.org/10.1007/s12223-0080059-1.

EFSA (European Food Safety Authority) and ECDC (European Centre for Disease Prevention and Control). 2014. The European Union Summary Report on Trends and Sources of Zoonoses, Zoonotic Agents and Food-borne Outbreaks in 2012. EFSA J. 12:3547. https://doi.org/10.2903/j.efsa.2014.3547.

EFSA. 2015. Scientific opinion on the public health risks related to the consumption of raw drinking milk. EFSA J. 13:3940-4035. https://doi.org/10.2903/j.efsa.2015.3940.

Esko, J. D., and N. Sharon. 2009. Microbial Lectins: Hemagglutinins, Adhesins, and Toxins. Cold Spring Harbor Press, New York, NY.

Evers, J. M., R. G. Haverkamp, S. E. Holroyd, G. B. Jameson, D. D. S. Mackenzie, and O. J. McCarthy. 2008. Heterogeneity of milk fat globule membrane structure and composition as observed using fluorescence microscopy techniques. Int. Dairy J. 18:1081-1089. https://doi.org/10.1016/j.idairyj.2008.06.001.

Fantini, J., D. Hammache, O. Delezay, N. Yahi, C. Andre-Barres, I. Rico-Lattes, and A. Lattes. 1997. Synthetic soluble analogs of galactosylceramide (galcer) bind to the V3 domain of HIV-1 gp120 and inhibit HIV-1-induced fusion and entry. J. Biol. Chem. 272:7245-7252. https://doi.org/10.1074/jbc.272.11.7245.

Gallier, S., A. Ye, and H. Singh. 2012. Structural changes of bovine milk fat globules during in vitro digestion. J. Dairy Sci. 95:35793592. https://doi.org/10.3168/jds.2011-5223.

Ghosh, S., and R. K. Mehla. 2012. Influence of dietary supplementation of prebiotics (mannanoligosaccharide) on the performance of crossbred calves. Trop. Anim. Health Prod. 44:617-622. https:// doi.org/10.1007/s11250-011-9944-8.

Gopal, P. K., and H. S. Gill. 2000. Oligosaccharides and glycoconjugates in bovine milk and colostrum. Br. J. Nutr. 84(Suppl. 1):S6974 .

Goudedranche, H., J. Fauquant, and J.-L. Maubois. 2000. Fractionation of globular milk fat by membrane microfiltration. Lait 80:9398.

Guri, A., M. Griffiths, C. M. Khursigara, and M. Corredig. 2012. The effect of milk fat globules on adherence and internalization of Salmonella enteritidis to HT-29 cells. J. Dairy Sci. 95:6937-6945. https://doi.org/10.3168/jds.2012-5734.

Haiko, J., and B. Westerlund-Wikström. 2013. The role of the bacterial flagellum in adhesion and virulence. Biology (Basel) 2:12421267. https://doi.org/10.3390/biology2041242.

Harrison, R. 2006. Milk xanthine oxidase: Properties and physiological roles. Int. Dairy J. 16:546-554. https://doi.org/10.1016/j. idairyj.2005.08.016.

Heid, H. W., and T. W. Keenan. 2005. Intracellular origin and secretion of milk fat globules. Eur. J. Cell Biol. 84:245-258. https://doi. org/10.1016/j.ejcb.2004.12.002.

Hickey, C. D., J. J. Sheehan, M. G. Wilkinson, and M. A. E. Auty. 2015. Growth and location of bacterial colonies within dairy foods using microscopy techniques: A review. Front. Microbiol. 6: https://doi.org/10.3389/fmicb.2015.00099.

Jaglic, Z., M. Desvaux, A. Weiss, L. L. Nesse, R. L. Meyer, K. Demnerova, H. Schmidt, E. Giaouris, A. Sipailiene, P. Teixeira, M. Kačániová, C. U. Riedel, and S. Knøchel. 2014. Surface adhesins and exopolymers of selected foodborne pathogens. Microbiology 160:2561-2582. https://doi.org/10.1099/mic.0.075887-0.

Jensen, R. G., A. M. Ferris, and C. J. Lammi-Keefe. 1992. Lipids in human milk and infant formulas. Annu. Rev. Nutr. 12:417-441.

Kai, T. M. K., and A. Aotearoa. 2009. Microbiological risk assessment of raw cow milk. Food Standards Australia New Zealand, Australia.

Kaper, J. B., J. P. Nataro, and H. L. Mobley. 2004. Pathogenic Escherichia coli. Nat. Rev. Microbiol. 2:123-140. https://doi. org/10.1038/nrmicro818.

Keenan, T. W., D. P. Dylewski, T. A. Woodford, and R. H. Ford. 1983. Origin of milk fat globules and the nature of the milk fat globule membrane. Pages 83-118 in Developments in Dairy Chemistry — 2. Springer, Dordrecht, the Netherlands.

Keenan, T. W., and S. Patton. 1995. The milk lipid globule membrane. Pages 5-50 in Handbook of Milk Composition. Academic Press, San Diego, CA.

Kelly, C. G., and J. S. Younson. 2000. Anti-adhesive strategies in the prevention of infectious disease at mucosal surfaces. Expert Opin. Investig. Drugs 9:1711-1721. https://doi. org/10.1517/13543784.9.8.1711

Kim, H. H., and R. Jimenez-Flores. 1995. Heat-induced interactions between the proteins of milk fat globule membrane and skim milk. J. Dairy Sci. 78:24-35. https://doi.org/10.3168/jds.S00220302(95) 76612-7.

Klemm, P., and M. A. Schembri. 2000. Bacterial adhesins: Function and structure. Int. J. Med. Microbiol. 290:27-35. https://doi. org/10.1016/S1438-4221(00)80102-2.

Klemm, P., R. M. Vejborg, and V. Hancock. 2010. Prevention of bacterial adhesion. Appl. Microbiol. Biotechnol. 88:451-459. https:// doi.org/10.1007/s00253-010-2805-y.

Kobylka, D., and K. L. Carraway. 1972. Proteins and glycoproteins of the milk fat globule membrane. Biochim. Biophys. Acta Biomembr. 288:282-295. https://doi.org/10.1016/0005-2736(72)90249-0.

Kuo, M.-I., and S. Gunasekaran. 2009. Effect of freezing and frozen storage on microstructure of mozzarella and pizza cheeses. Food Sci. Technol. (Campinas) 42:9-16. https://doi.org/10.1016/j. lwt.2008.07.003

Kvistgaard, A. S., L. T. Pallesen, C. F. Arias, S. López, T. E. Petersen, C. W. Heegaard, and J. T. Rasmussen. 2004. Inhibitory effects of human and bovine milk constituents on rotavirus infections. J. Dairy Sci. 87:4088-4096. https://doi.org/10.3168/jds. S0022-0302(04)73551-1.

Laloy, E., J. Vuillemard, M. El Soda, and R. E. Simard. 1996. Influence of the fat content of cheddar cheese on retention and localization of starters. Int. Dairy J. 6:729-740.

Le, T. T., T. Van de Wiele, T. N. H. Do, G. Debyser, K. Struijs, B. Devreese, K. Dewettinck, and J. Van Camp. 2012. Stability of milk fat globule membrane proteins toward human enzymatic gastrointestinal digestion. J. Dairy Sci. 95:2307-2318. https://doi. org/10.3168/jds.2011-4947.

Lebrero, E. A., P. C. Moreno, S. G. Arnau, G. Ros, T. Secretary, and S. G. Arnau. 2015. Report of the scientific committee of the Spanish agency for consumer affairs, food safety and nutrition (AECOSAN) on the microbiological risks associated with the consumption of raw milk and raw milk-based products. Rev. Com. Cient. Aecosan 3:45-78

Lis, H., and N. Sharon. 1998. Lectins: Carbohydrate-specific proteins that mediate cellular recognition. Chem. Rev. 98:637-674. https:// doi.org/10.1021/cr940413g.

Lopez, C. 2005. Focus on the supramolecular structure of milk fat in dairy products. Reprod. Nutr. Dev. 45:497-511. https://doi. org $/ 10.1051 /$ rnd:2005034

Lopez, C. 2011. Milk fat globules enveloped by their biological membrane: Unique colloidal assemblies with a specific composition and structure. Curr. Opin. Colloid Interface Sci. 16:391-404. https:// doi.org/10.1016/j.cocis.2011.05.007.

Lopez, C., V. Briard-Bion, O. Ménard, E. Beaucher, F. Rousseau, J. Fauquant, N. Leconte, and B. Robert. 2011. Fat globules selected from whole milk according to their size: Different compositions and structure of the biomembrane, revealing sphingomyelin-rich 
domains. Food Chem. 125:355-368. https://doi.org/10.1016/j. foodchem.2010.09.005.

Lopez, C., C. Cauty, and F. Guyomarc'h. 2015. Organization of lipids in milks, infant milk formulas and various dairy products: role of technological processes and potential impacts. Dairy Sci. Technol. 95:863-893. https://doi.org/10.1007/s13594-015-0263-0.

Lopez, C., M.-N. Madec, and R. Jimenez-Flores. 2010. Lipid rafts in the bovine milk fat globule membrane revealed by the lateral segregation of phospholipids and heterogeneous distribution of glycoproteins. Food Chem. 120:22-33. https://doi.org/10.1016/j. foodchem.2009.09.065.

Lopez, C., M.-B. Maillard, V. Briard-Bion, B. Camier, and J. A. Hannon. 2006. Lipolysis during ripening of Emmental cheese considering organization of fat and preferential localization of bacteria. J. Agric. Food Chem. 54:5855-5867. https://doi.org/10.1021/ jf060214l.

MacGibbon, A. K. H., and M. W. Taylor. 2006. Composition and structure of bovine milk lipids. Adv. Dairy Chem. 2:1-42. https:// doi.org/10.1007/0-387-28813-9_1.

Maldonado-Gomez, M. X., H. Lee, D. Barile, M. Lu, and R. W. Hutkins. 2015. Adherence inhibition of enteric pathogens to epithelial cells by bovine colostrum fractions. Int. Dairy J. 40:24-32. https:// doi.org/10.1016/j.idairyj.2014.08.014.

Martin, H. M., J. T. Hancock, V. Salisbury, and R. Harrison. 2004 Role of xanthine oxidoreductase as an antimicrobial agent. Infect. Immun. 72:4933-4939. https://doi.org/10.1128/IAI.72.9.49334939.2004 .

Martin-Sosa, S., M.-J. Martin, and P. Hueso. 2002. The sialylated fraction of milk oligosaccharides is partially responsible for binding to enterotoxigenic and uropathogenic Escherichia coli human strains. J. Nutr. 132:3067-3072.

Martinovic, A., K. M. Moe, E. Romeih, B. Aideh, F. K. Vogensen, H. Østlie, and S. Skeie. 2013. Growth of adjunct Lactobacillus casei in cheddar cheese differing in milk fat globule membrane components. Int. Dairy J. 31:70-82. https://doi.org/10.1016/j. idairyj.2013.02.009.

Mather, I. H. 2000. A review and proposed nomenclature for major proteins of the milk-fat globule membrane. J. Dairy Sci. 83:203247. https://doi.org/10.3168/jds.S0022-0302(00)74870-3.

Mather, I. H., and T. W. Keenan. 1998. Origin and secretion of milk lipids. J. Mammary Gland Biol. Neoplasia 3:259-273. https://doi. org/10.1023/A:1018711410270.

McWilliams, B. D., and A. G. Torres. 2014. Enterohemorrhagic Escherichia coli adhesins. Microbiol. Spectr. 2:EHEC00032013. https:// doi.org/10.1128/microbiolspec.EHEC-0003-2013.

Ménard, O., S. Ahmad, F. Rousseau, V. Briard-Bion, F. Gaucheron, and C. Lopez. 2010. Buffalo vs. cow milk fat globules: Size distribution, zeta-potential, compositions in total fatty acids and in polar lipids from the milk fat globule membrane. Food Chem. 120:544-551. https://doi.org/10.1016/j.foodchem.2009.10.053.

Mesilati-Stahy, R., H. Malka, and N. Argov-Argaman. 2015. Influence of glucogenic dietary supplementation and reproductive state of dairy cows on the composition of lipids in milk. Animal 9:10081015. https://doi.org/10.1017/S1751731115000099.

Michalski, M.-C., J.-Y. Gassi, M.-H. Famelart, N. Leconte, B. Camier, F. Michel, and V. Briard. 2003. The size of native milk fat globules affects physico-chemical and sensory properties of Camembert cheese. Lait 83:131-143. https://doi.org/10.1051/lait:2003003.

Mills, S., R. P. Ross, C. Hill, G. F. Fitzgerald, and C. Stanton. 2011. Milk intelligence: Mining milk for bioactive substances associated with human health. Int. Dairy J. 21:377-401. https://doi. org/10.1016/j.idairyj.2010.12.011.

Minke, W. E., C. Roach, W. G. Hol, and C. L. Verlinde. 1999. Structure-based exploration of the ganglioside GM1 binding sites of Escherichia coli heat-labile enterotoxin and cholera toxin for the discovery of receptor antagonists. Biochemistry 38:5684-5692. https://doi.org/10.1021/bi982649a.

Newburg, D. S., G. M. Ruiz-Palacios, and A. L. Morrow. 2005. Human milk glycans protect infants against enteric pathogens. Annu. Rev. Nutr. 25:37-58. https://doi.org/10.1146/annurev. nutr.25.050304.092553.
Ofek, I., D. L. Hasty, and N. Sharon. 2003. Anti-adhesion therapy of bacterial diseases: Prospects and problems. FEMS Immunol. Med. Microbiol. 38:181-191. https://doi.org/10.1016/S09288244(03)00228-1.

Park, E. J., M. Suh, B. Thomson, D. W. L. Ma, K. Ramanujam, A. B. R. Thomson, and M. T. Clandinin. 2007. Dietary ganglioside inhibits acute inflammatory signals in intestinal mucosa and blood induced by systemic inflammation of Escherichia coli lipopolysaccharide. Shock 28:112-117. https://doi.org/10.1097/ SHK.0b013e3180310fec.

Parker, P., L. Sando, R. Pearson, K. Kongsuwan, R. L. Tellam, and S. Smith. 2010. Bovine Muc1 inhibits binding of enteric bacteria to Caco-2 cells. Glycoconj. J. 27:89-97. https://doi.org/10.1007/ s10719-009-9269-2.

Peterson, J. A., S. Patton, and M. Hamosh. 1998. Glycoproteins of the human milk fat globule in the protection of the breast-fed infant against infections. Biol. Neonate 74:143-162. https://doi. org/10.1159/000014020.

Pizarro-Cerdá, J., and P. Cossart. 2006. Bacterial adhesion and entry into host cells. Cell 124:715-727. https://doi.org/10.1016/j. cell.2006.02.012.

Pizarro-Cerdá, J., A. Kuhbacher, and P. Cossart. 2012. Entry of Listeria monocytogenes in mammalian epithelial cells: An updated view. Cold Spring Harb. Perspect. Med. 2:a010009. https://doi org/10.1101/cshperspect.a010009.

Rodriguez, L., J. F. Fernández Garayzabal, J. A. Vazquez Boland, E. Rodriguez Ferri, and G. Suarez Fernández. 1985. Isolation de micro-organismes du genre Listeria à partir de lait cru destiné à la consommation humaine. Can. J. Microbiol. 31:938-941.

Quintero, M., M. Maldonado, M. Perez-Munoz, R. Jimenez, T. Fangman, J. Rupnow, A. Wittke, M. Russell, and R. Hutkins. 2011. Adherence inhibition of Cronobacter sakazakii to intestinal epithelial cells by prebiotic oligosaccharides. Curr. Microbiol. 62:1448-1454. https://doi.org/10.1007/s00284-011-9882-8.

Quintero-Villegas, M. I., B. B. Aam, J. Rupnow, M. Sørlie, V. G. H. Eijsink, and R. W. Hutkins. 2013. Adherence inhibition of enteropathogenic Escherichia coli by chitooligosaccharides with specific degrees of acetylation and polymerization. J. Agric. Food Chem. 61:2748-2754. https://doi.org/10.1021/jf400103g.

Riccio, P. 2004. The proteins of the milk fat globule membrane in the balance. Trends Food Sci. Technol. 15:458-461. https://doi. org/10.1016/j.tifs.2003.12.005.

Rivero-Urgëll, M., and A. Santamaria-Orleans. 2001. Oligosaccharides: Application in infant food. Early Hum. Dev. 65:S43-S52. https:// doi.org/10.1016/S0378-3782(01)00202-X.

Rombaut, R., and K. Dewettinck. 2007. Thermocalcic aggregation of milk fat globule membrane fragments from acid buttermilk cheese whey. J. Dairy Sci. 90:2665-2674. https://doi.org/10.3168/ jds.2006-711.

Ross, S. A., J. A. Lane, M. Kilcoyne, L. Joshi, R. M. Hickey, and R. M. Hickeya. 2016. Defatted bovine milk fat globule membrane inhibits association of enterohaemorrhagic Escherichia coli O157:H7 with human HT-29 cells. Int. Dairy J. 59:36-43. https://doi. org/10.1016/j.idairyj.2016.03.001.

Rubinchik, S., A. Seddon, and A. V. Karlyshev. 2012. Molecular mechanisms and biological role of Campylobacter jejuni attachment to host cells. Eur. J. Microbiol. Immunol. (Bp.) 2:32-40. https://doi. org/10.1556/EuJMI.2.2012.1.6.

Rueda, R., J. L. Sabatel, J. Maldonado, J. A. Molina-Font, and A. Gil. 1998. Addition of gangliosides to an adapted milk formula modifies levels of fecal Escherichia coli in preterm newborn infants. J. Pediatr. 133:90-94. https://doi.org/10.1016/S0022-3476(98)70184-2.

Sabharwal, H., S. Sjoblad, and A. Lunblad. 1991. Affinity chromatographic identification and quantitation of blood group A-active oligosaccharides in human milk and feces of breast-fed infants. J. Pediatr. Gastroenterol. Nutr. 12:474-479.

Sánchez-Juanes, F., J. M. Alonso, L. Zancada, and P. Hueso. 2009 Glycosphingolipids from bovine milk and milk fat globule membranes: A comparative study. adhesion to enterotoxigenic Escherichia coli strains. Biol. Chem. 390:31-40. https://doi.org/10.1515/ BC.2009.003. 
Sando, L., R. Pearson, C. Gray, P. Parker, R. Hawken, P. C. Thomson, J. R. S. Meadows, K. Kongsuwan, S. Smith, and R. L. Tellam. 2009. Bovine muc1 is a highly polymorphic gene encoding an extensively glycosylated mucin that binds bacteria. J. Dairy Sci. 92:5276-5291. https://doi.org/10.3168/jds.2009-2216.

Schroten, H., F. G. Hanisch, R. Plogmann, J. Hacker, G. Uhlenbruck, R. Nobis-bosch, and V. Wahn. 1992. Inhibition of adhesion of Sfimbriated Escherichia coli to buccal epithelial cells by human milk fat globule membrane components: Function of mucins in the nonimmunoglobulin fraction. Infect. Immun. 60:2893-2899.

Séverin, S., and X. Wenshui. 2005. Milk biologically active components as nutraceuticals. Crit. Rev. Food Sci. Nutr. 45:645-656. https:// doi.org/10.1080/10408690490911756. (review)

Shahriar, F., M. Ngeleka, J. R. Gordon, and E. Simko. 2006. Identification by mass spectroscopy of F4ac-fimbrial-binding proteins in porcine milk and characterization of lactadherin as an inhibitor of F4ac-positive Escherichia coli attachment to intestinal villi in vitro. Dev. Comp. Immunol. 30:723-734. https://doi.org/10.1016/j. dci.2005.10.003.

Sharma, S. K., and D. G. Dalgleish. 1993. Interactions between milk serum proteins and synthetic fat globule membrane during heating of homogenized whole milk. J. Agric. Food Chem. 41:1407-1412.

Sharon, N. 2006. Carbohydrates as future anti-adhesion drugs for infectious diseases. Biochim. Biophys. Acta 1760:527-537. https:// doi.org/10.1016/j.bbagen.2005.12.008.

Shimizu, M., K. Yamauchi, and C. Kanno. 1979. Proteolytic digestion of milk fat globule membrane proteins. Milchwissenschaft 34:666-668.

Simeoni, U., B. Berger, J. Junick, M. Blaut, S. Pecquet, E. Rezzonico, D. Grathwohl, N. Sprenger, H. Brüssow, H. Szajewska, J.-M. Bartoli, V. Brevaut-Malaty, M. Borszewska-Kornacka, W. Feleszko, P. François, C. Gire, M. Leclaire, J.-M. Maurin, S. Schmidt, A. Skórka, C. Squizzaro, and J.-J. Verdot. 2015. Gut microbiota analysis reveals a marked shift to bifidobacteria by a starter infant formula containing a synbiotic of bovine milk-derived oligosaccharides and Bifidobacterium animalis ssp. lactis $\mathrm{cncm}$ i-3446. Environ. Microbiol. https://doi.org/10.1111/1462-2920.13144.

Simon, P. M., P. Goode, A. Mobasseri, and D. Zopf. 1997. Inhibition of Helicobacter pylori binding to gastrointestinal epithelial cells by sialic acid-containing oligosaccharides. Infect. Immun. 65:750-757.

Sohanpal, B. K., S. El-Labany, M. Lahooti, J. A. Plumbridge, and I. C. Blomfield. 2004. Integrated regulatory responses of FimB to N-acetylneuraminic (sialic) acid and GlcNac in Escherichia coli k-12. Proc. Natl. Acad. Sci. USA 101:16322-16327. https://doi. org/10.1073/pnas.0405821101.

Sprong, R., M. F. Hulstein, and R. van der Meer. 2002. Bovine milk fat components inhibit food-borne pathogens. Int. Dairy J. 12:209 215. https://doi.org/10.1016/S0958-6946(01)00139-X.
Sprong, R. C., M. F. Hulstein, and R. Van der Meer. 2001. Bactericidal activities of milk lipids. Antimicrob. Agents Chemother. 45:1298-1301. https://doi.org/10.1128/AAC.45.4.1298-1301.2001.

Stahlhut, S. G., S. Chattopadhyay, C. Struve, S. J. Weissman, P. Aprikian, S. J. Libby, F. C. Fang, K. A. Krogfelt, and E. V. Sokurenko. 2009. Population variability of the FimH type 1 fimbrial adhesin in Klebsiella pneumoniae. J. Bacteriol. 191:1941-1950. https://doi.org/10.1128/JB.00601-08.

Steil, D., C.-L. Schepers, G. Pohlentz, N. Legros, J. Runde, H.-U. Humpf, H. Karch, and J. Müthing. 2015. Shiga toxin glycosphingolipid receptors of vero-b4 kidney epithelial cells and their membrane microdomain lipid environment. J. Lipid Res. 56:2322-2336. https://doi.org/10.1194/jlr.M063040.

Struijs, K., T. Van de Wiele, T. T. Le, G. Debyser, K. Dewettinck, B. Devreese, and J. Van Camp. 2013. Milk fat globule membrane glycoproteins prevent adhesion of the colonic microbiota and result in increased bacterial butyrate production. Int. Dairy J. 32:99-109. https://doi.org/10.1016/j.idairyj.2013.05.001.

Tao, N., E. J. DePeters, S. Freeman, J. B. German, R. Grimm, and C. B. Lebrilla. 2008. Bovine milk glycome. J. Dairy Sci. 91:3768-3778. https://doi.org/10.3168/jds.2008-1305.

Tao, N., E. J. DePeters, J. B. German, R. Grimm, and C. B. Lebrilla 2009. Variations in bovine milk oligosaccharides during early and middle lactation stages analyzed by high-performance liquid chromatography-chip/mass spectrometry. J. Dairy Sci. 92:2991-3001. https://doi.org/10.3168/jds.2008-1642.

Tellez, A., M. Corredig, A. Guri, R. Zanabria, M. W. Griffiths, and V. Delcenserie. 2012. Bovine milk fat globule membrane affects virulence expression in Escherichia coli O157:H7. J. Dairy Sci. 95:6313-6319. https://doi.org/10.3168/jds.2012-5560.

Truong, T., M. Palmer, N. Bansal, and B. Bhandari. 2016. An Overview of Milk Fat Globules. Springer International Publishing, New York, NY.

Virkola, R., J. Parkkinen, J. Hacker, and T. K. Korhonen. 1993. Sialyloligosaccharide chains of laminin as an extracellular matrix target for S fimbriae of Escherichia coli. Infect. Immun. 61:4480-4484.

Walstra, P. 1995. Physical chemistry of milk fat globules. Adv. Dairy Chem. 2:131-178.

Walstra, P., J. T. M. Wouters, and T. J. Geurts. 2005. Dairy Science and Technology. 2nd ed. CRC Press/Taylor \& Francis Group LLC, Boca Raton, FL.

Wang, X., S. Hirmo, and R. Wille. 2001. Inhibition of Helicobacter pylori infection by bovine milk glycoconjugates in a BAlb/cA mouse model. J. Med. Microbiol. 50:430-435.

Wooding, F. B. P., and T. J. Sargeant. 2015. Immunocytochemical evidence for Golgi vesicle involvement in milk fat globule secretion. J. Histochem. Cytochem. 63:943-951. https://doi. org/10.1369/0022155415608918. 